\title{
Alienation in Carol Plum-Ucci's The Body of Christopher Creed ${ }^{*}$
}

\author{
YANG Chun \\ China Youth University of Political Studies, Beijing, China
}

\begin{abstract}
In Carol Plum-Ucci's young adult novel The Body of Christopher Creed (2000), the indeterminacy and mystery of the theme of missing people renders Carol Plum-Ucci a huge space of imagination to depict people's different reactions to the sudden disappearance of Christopher Creed and the consequences brought by their reactions. Through the twists, turns, and suspense provided by Carol Plum-Ucci in the story, readers can get a better look at teenagers' alienation permeated in the novel. Based on theories of alienation and close reading of the text, the present paper aims at exploring the complex implications of the alienation demonstrated in the novel.
\end{abstract}

Keywords: The Body of Christopher Creed, Carol Plum-Ucci, theme, alienation

\section{Introduction}

Carol Plum-Ucci's is an American young adult novelist. The Body of Christopher Creed (2000) is her most famous work, for which she won a Michael L. Printz Award in 2002 and was named a Finalist to the Edgar Allan Poe Award. It tells the story of Torey Adams, a high school junior, whose life is totally altered when he tries to solve the mysterious disappearance of Christopher Creed, one of his classmates.

During an interview, facing the question that "[m]any of your books feature characters who are missing, possibly dead. What do you hope readers will take away from your exploration of these ambiguous situations?" (Plum-Ucci, 2008, p. 255), Carol Plum-Ucci once answered:

I don't really know why I keep revisiting the theme of missing people. I have Chris Creed, of course, and Lani Garver, and Casey Carmody in The Night My Sister Went Missing. It could be something as simple as that I have a peaceful nature and just don't have what it would take to create a serial killer for intrigue. It could also have something to do with my fixation on spirituality. Missing people tend o take on a divine status. They become mythical and may personify my journey through the mysteries of life and death. (Plum-Ucci, 2008, p. 255)

In The Body of Christopher Creed, the indeterminacy and mystery of the theme of missing people renders Carol Plum-Ucci a huge space of imagination to depict people's different reactions to the sudden disappearance of Christopher Creed and the consequences brought by their reactions. Through the twists, turns, and suspense provided by Carol Plum-Ucci in the story, readers can get a better look at teenagers' alienation permeated in the novel.

The term "alienation" has been used over the ages with varied meanings. The older meaning in which "alienation" was used was to denote an insane person. In the last century, the word "alienation" was used by

\footnotetext{
* Acknowledgements: This paper is supported by China Youth University of Political Studies.

YANG Chun, associate professor, master, Foreign Language Department, China Youth University of Political Studies.
} 
Hegel and Marx, referring to a state of self-estrangement. Based on his observation that in emerging industrial production under capitalism, workers inevitably lose control of their lives and selves by not having any control of their work, Marx developed his theory of alienation. In Marx's system, "alienation" is called that condition of man where his "own act becomes to him an alien power, standing over and against him, instead of being ruled by him" (Fromm, 2002, p. 117).

Many other contemporary theorists contributed a lot to the development of the theories of alienation. In The Sane Society, when discussing the effects of Capitalism on personality, German sociologist and humanistic philosopher Fromm Erich gives a classic definition of alienation and states that:

By alienation is meant a mode of experience in which the person experiences himself as an alien. He has become, one might say, estranged from himself. He does not experience himself as the center of his world, as the creator of his own acts - but his acts and their consequences have become his masters, whom he obeys, or whom he may even worship. The alienated person is out of touch with himself as he is out of touch with any other person. He, like the others, are experienced as things are experienced; with the senses and with common sense, but at the same time without being related to oneself and to the world outside productively. (Fromm, 2002, p. 117)

As a sociological concept, alienation is,

A condition in social relationships reflected by a low degree of integration or common values and a high degree of distance or isolation between individuals, or between an individual and a group of people in a community or work environment. (Ankony, 1999, p. 128)

Melvin Seeman in his pioneering article "On the Meaning of Alienation" distinguished five dimensions of alienation:

(1) powerlessness: the expectancy or probability held by individual that his own behavior cannot determine the occurrence of the outcomes, or reinforcement, he seeks;

(2) meaninglessness: a low expectancy that satisfactory predictions about future outcomes of behavior can be made;

(3) normlessness: a high expectancy that socially unapproved behaviors are required to achieve given goal;

(4) social isolation: assigning low reward value to goals or beliefs that are typically highly valued in the given society;

(5) self-estrangement: the degree of dependence of the given behavior upon anticipated future rewards, i.e. upon rewards that lie outside the activity itself (Seeman, 1959, p. 784).

Theories of the alienation are still under the evolution. Despite the debate over a wide range of intellectual and political issues during its evolution, a constant focus is placed on its critical applications in the social sciences, in empirical research as well as in literary criticism. Based on theories of alienation and close reading of the text, the present paper aims at exploring the complex implications of alienation demonstrated in the novel.

\section{Christopher Creed's Alienation}

Christopher Creed is the missing boy in the novel who disappears without any trace except a goodbye e-mail to the principal, Glen Ames. His sudden disappearance triggers a chain of reactions in the town Steepleton where on the surface people live quite a content and peaceful life. At first, people are confused. They do not know what leads to Chris Creed's disappearance since there is no reason for such behavior in Steepleton: 
In Steepleton you could ride your bike to the Wawa - our only convenient store - and leave it out front without a padlock. You could always meet your girlfriend after dark because there wasn't any reason for a mom or dad to say that a girl couldn't walk around outside after dark. Even the boons, the really bad kids, went back to the boondocks after school and kind of stopped existing to us until school the next day. Kids from Steepleton played sports, joined clubs, applied to out-of-state colleges, got cars for graduation. There wasn't much to commit suicide over... If you were looking at surface stuff like that. (Plum-Ucci, 2008, p. 18)

Throughout the whole novel, Chris Creed's parents believe her son had "a very good life" (Plum-Ucci, 2008, p. 228) and could not have wanted to kill himself or run away. Mrs. Creed even accuses Bo Richardson, one of the boons, of murdering her son even though she could not find any evidence. The mystery around Creed's disappearance arouses Torrey Adams' curiosity and makes him more concerned about Creed's disappearance and try to find out what is behind his disappearance. With his search develops, from Torrey's point of view, readers will gradually realize that it is Chris Creed's alienation that finally results in his disappearance.

First, Chris Creed's alienation is from school. His peers treat him as a weirdo. They bully him and are repulsive to him. Torrey, even a good boy, has prejudice against Chris Creed and sometimes treats him "heartlessly":

But even in Steepleton had its weird kids, and Chris had been one of them. I think the worst thing about him was his undying combo of big mouth and huge grin. He seemed to forget from one day to the next who he had pissed off. He'd come bounding up to the same kids who had told him yesterday to get lost like he was their best friend. Like his entire track record as an annoying person didn't exist. In my whole life I had never met another person like Creed. ...Bo Richardson-had pushed Chris off the top bleacher in the gym the year before and set him on crutches for a few weeks. Those boons could be scary, but we still blamed Chris as much as we blamed them. He was weird as they were charged up. (Plum-Ucci, 2008, pp. 18-19)

At the end of the novel, Torrey is rather sad and sorrowful about his previous attitude towards Chris Creed. He even thanks to Chris Creed in helping him to realize how mean he was. At last, Torrey knows that Chris Creed "was an innocent kid, a victim" (Plum-Ucci, 2008, p. 242) and he shares some part of himself with Chris.

Second, Chris Creed's alienation is from his family. His parents strictly control him. He has no freedom of his own. As Ali McDermott tells Torrey about Chris Creed's mother since Ali's window has a clear view into Chris's bedroom:

She was all over Chris, all the time. He had no privacy, no choices of clothes, no CDs... He had an eight o'clock curfew in the summers. How is a kid supposed to make friends when he's got an eight o'clock curfew? (Plum-Ucci, 2008, p. 111)

There is no communication, no trust between Chris and his parents. Chris has to hide his diary in a picture frame on the wall, the only place safe from his mother's prying eyes. Chris's loneliness and awareness of alienation can be read from his e-mail to the principle, Mr. Ames before his disappearance:

I have a problem getting along with people. I know that people wish I were dead, and at this moment in time I see no alternative but to accommodate them in this wish. I have a wish. Not that anybody cares, but if anybody cared over the years, it was you. Here is my wish. I wish that I had been born somebody else. (Plum-Ucci, 2008, p. 27)

Chris Creed's alienation represents the estrangement among young generation and estrangement between young generation and old generation because of bias, prejudice, and lack of communication. 


\section{Torrey Adams' Alienation}

Torrey Adams is the narrator of the novel. Before the sudden disappearance of Chris Creed, he thinks he lives a perfect life with a wealthy family and a lot of friends. But when he starts to solve the mystery of Chris's disappearance, his life is totally altered. Awareness of alienation begins to appear in his life.

At school, Torrey begins to feel alienated from his friends Alex, Ryan, Renee, and his girlfriend Leandra when they joke about Chris's disappearance and seem to take it lightly. He even feels the hostility and antagonism from his friends when he comes close with Ali McDermott, a girl with the bad reputation of slut and Bo Richardson, a "boon". "Boon" is a somewhat derogatory term in town Steepleton that refers to a group of students who come from poorer homes and are usually treated as bad kids. The cool kids at high school look down on them and treat them as lower class.

Torrey becomes further distanced from his friends when the wide spread of rumors and gossips say that Torrey is also involved in the murder of Chris with Bo Richardson. While the truth is that Bo Richardson has nothing to do with Chris's disappearance. He has a mean exterior but cares deeply for his girlfriend Ali McDermott, her brother Greg, and his own siblings. He is also loyal to Torey. In order to protect Torrey from being charged, he confesses to the blackmail phone call to Mrs. Creed despite his innocence.

But Mrs. Creed and some people in the town would not believe in Bo Richardson because of their moral hypocrisy, their cowardliness in taking the responsibility, and their unfair judgment to others who are different from them, just as Torey's mother says: "Nobody wants to take responsibility. Nobody wants to admit they had a part in it. So, they spend a lot of time pointing the finger, and things just get worse and worse" (Carol Plum-Ucci, 2008, p. 114).

The same tragedy happed in Steepleton several years ago. A teenager boy called Digger Haines ran away from home. He was a high school footballer player. He lost his leg in a motorbike accident. His football days were over, as were his dream of having a military career like his father's. "But it's there, part of the little-town mentality, that thing that makes people want to sniff out neighbors who are weird or less fortune, and talk about those people's bad luck to establish their own goodness" (Plum-Ucci, 2008, p. 11). Some kids started calling Digger "gimp" and "pirate" and other names behind his back. One day, Digger left a note to his father and disappeared saying to "find himself". Before the accident, Digger's father, Bob Haines was very proud of him and had always wanted Digger to go into the Marine Corps, play hero in Vietnam. The accident and Digger's disappearance were so difficult for him to accept that he started to blame the kids in Steepleton for calling Digger names and driving him away. The town responded by blaming Bob Haines for being unable to cope with his son who could no longer to meet his expectations and said it was the father who drove Digger away. Grief, humiliation, and self-accusation finally destroyed Bob Haines. One dark night, with his old World War II pistol in his belt, he crawled in one of the Indian burial caves and pulled the trigger. But Steepleton seemed to learn nothing from the tragedy since "nobody stopped believing that other people were more guilt than they were" (Plum-Ucci, 2008, p. 177). People are blind in seeing their own faults. They are easy to find someone at the disadvantage to be a scapegoat.

At the end of the story, since Torrey can no longer stand the rumors and gossips in Steepleton, he moves to a new town to begin his life. Through the course of finding the truth of Chris's disappearance, Torrey grows up and becomes mature. Finally, he realizes that "Chris was leaving to survive, not leaving to die" (Plum-Ucci, 2008 , p. 216). Chris's disappearance was only meant to save himself from a life that seemed unfair and did not 
make sense. He also realized that engendered by prejudice, hypocrisy, indifference, and lack of responsibility, alienation affects trust and friendship in social contact and hinders the development of social fair and justice.

\section{Conclusion}

When talking about the purpose of her writing, Carol Plum-Ucci once said:

Life is a journey, and I may not have always lived up to my ability, but I have always lived purposefully, and I guess readers get caught up with me, raising the questions, looking for the answers, looking to be a little more understanding, a little less judgmental, a little more merciful. I hope so. (Plum-Ucci, 2008, p. 259)

In The Body of Christopher Creed, through depicting the tragedy of Chris and Digger, Carol Plum-Ucci artistically presents teenager readers a horrible world where there is no trust, no compassion, and no awareness of responsibility among people. Alienation permeates not only in inter-family relation but also in social contact and alienated people search desperately for some way out, at the cost of their reputation as well as their lives.

Childhood is viewed as "the crucial formative period in the life of human being, the time for basic education about the nature of the world, how to live in it (...) what to believe, what and how to think" (James, 2009 , p. 15). Exposing the dark side of humanity will instruct young people about the true meaning of life. From this perspective, Carol Plum-Ucci has successfully fulfilled her purpose of writing.

\section{References}

Ankony, R. C. (1999). The impact of perceived alienation on police officers' sense of mastery and subsequent motivation for proactive enforcement. Policing: An International Journal of Police Strategies and Management, 22(2), 35.

Braune, J. (2014). Erich Fromm's revolutionary hope: Prophetic messianism as a critical theory of the future. Rotterdam, The Netherlands: Sense Publishers.

Fromm, E. (2002). The sane society. Abingdon, Oxon, United Kingdom: Routledge Classics.

Geyer, R. F., \& Schweitzer, D. R. (Eds.). (1976). Theories of alienation: Critical perspectives in philosophy and the social sciences. Leiden: H. E. Stenfert Kroese.

James, K. (2009). Death, gender and sexuality in contemporary adolescent literature. New York: Routledge.

Ollman, B. (1977). Alienation: Marx's conception of man in a capitalist society. Cambridge: Cambridge University Press.

Plum-Ucci, C. (2008). The body of Christopher Creed. New York: Houghton Mifflin Harcourt Publishing Company.

Rehmann, J. (2013). Theories of ideology: The powers of alienation and subjection. Leiden, The Netherlands: Koninklijke Brill $\mathrm{NV}$.

Seeman, M. (1959). On the meaning of alienation. American Sociological Review, 24(6), 18. 